University of Nebraska - Lincoln

DigitalCommons@University of Nebraska - Lincoln

Investigations of the Ichthyofauna of

Nicaraguan Lakes

1976

Calcium and Other lons in Blood and Skeleton of Nicaraguan

Fresh-Water Shark

Marshall R. Urist

University of California

Follow this and additional works at: https://digitalcommons.unl.edu/ichthynicar

Part of the Aquaculture and Fisheries Commons

Urist, Marshall R., "Calcium and Other lons in Blood and Skeleton of Nicaraguan Fresh-Water Shark" (1976). Investigations of the Ichthyofauna of Nicaraguan Lakes. 42.

https://digitalcommons.unl.edu/ichthynicar/42

This Article is brought to you for free and open access by the Papers in the Biological Sciences at DigitalCommons@University of Nebraska - Lincoln. It has been accepted for inclusion in Investigations of the Ichthyofauna of Nicaraguan Lakes by an authorized administrator of DigitalCommons@University of Nebraska Lincoln. 
Reprinted from Science, September 21, 1962, Vol. 137, No. 3534, pages 984-986

Copyright (c) 1962 by the American Association for the Advancement of Science

\section{Calcium and Other Ions in \\ Blood and Skeleton of \\ Nicaraguan Fresh-Water Shark}

Abstract. The bull shark, Carcharhinus leucas, employing archaic but effective means of regulating the physical-chemical composition of its body fluids, thrives in tropical fresh-water rivers and lakes. The ionic strength of the serum and the concentrations of total solutes, calcium, urea, and other ions are below the levels found in marine elasmobranchs but higher than the levels in teleosts. The patterns of the calcium deposits of the vertebrae are identical in marine and fresh-water subspecies.

Migrations into fresh water of the bull sharks of Lake Nicaragua in Central America, Lake Sentani of western Dutch New Guinea, and the Ganges and other Asiatic rivers have been reported by Herre (1) and Boeseman (2). The physiology of these fishes presents extraordinary mechanisms of ion and osmotic regulation. Smith (3) reported a decrease in the serum concentration of urea with relatively little change in phosphate or chloride in small sharks and sawfish found in rivers of Malaya and Siam; no data were recorded about the other solutes of the blood. My previous research (4) has included work on the chemistry of calcium and the major components of the blood and skeleton of the bull shark of the Atlantic, Carcharhinus leucas, and 13 other species of marine elasmobranchs, but none were fresh-water migrants.

On 27 March 1962, one tarpon (Megalops atlanticus) and four bull sharks, three females and one male, ranging in length from 5 feet 11 inches to 7 feet 1 inch, were taken in southeastern Nicaragua from Rio San Juan (5) near El Castillo. Small fishes, alligators, and viscera of swine were used as bait, but only freshly caught tarpon brought results. The fish were photographed after exsanguination by cardiac puncture and section of the caudal artery. Blood was collected in thermos containers. Serum was separated immediately after the blood had clotted, with a hand-operated centrifuge and then was frozen in liquid nitrogen for transportation to Los Angeles. Vertebrae were excised and fixed in solutions of 10 percent formalin. Specimens of water were collected from Lake Nicaragua and the region of Rio San Juan in which the fish were caught. Chemical methods were the same as in previous reports (4); values given are the mean of three determinations on each specimen.

Photographs of two specimens were examined by Eugenie Clark and Stewart Springer but could not be positively identified as $C$. leucas. Possibly a subspecies can be recognized in which (i) the first dorsal fin is behind the pectoral fins, (ii) the third gill slit is short, and (iii) the dental formula is identical. There is now considerable uncertainty (6) about whether the data collected to date can justify two subspecies, C. leucas leucas and C. leucas nicaraguensis; only a statistically significant number of specimens can resolve this situation. The limits of the range of $C$. leucas nicaraguensis is not known. The general assumption is that it originally inhabited oceanic lakes extending from the sea, adjusted to fresh water when the salt water turned fresh by a slow process of dilution, and became landlocked by historic earthquakes that raised the bedrock and produced the rapids of Rio San Juan. At El Castillo, El Toro rapids have channels through them that I found were easily passable for large tarpon, sharks, and even fishermen traveling in dugout canoes during the dry season.

The vertebrae of the shark of Nicaragua were sectioned for radiographic examination of the calcium deposits and for comparison with typical specimens of $C$. leucas which had been collected in the Atlantic Ocean and supplied by Clark. The configurations of the calcium deposits are exactly the same, and somewhat similar to those of other Carcharhinidae. The vertebrae of tarpon consist of true bone rather than calcified cartilage (Fig. 1).

Analyses of waters of Nicaragua revealed typical medium soft fresh water. In Lago de Nicaragua, and Rio San Juan, respectively, such analyses showed the following ions (in millimoles per liter): total ions, 8.5 and $5.1 ; \mathrm{Na}, 1.3$ and $0.7 ; \mathrm{K}, 0.1$ and $0.1 ; \mathrm{Ca}, 0.9$ and $0.8 ; \mathrm{Mg}, 0.6$ and $0.2 ; \mathrm{Cl}, 1.8$ and 0.8 ;

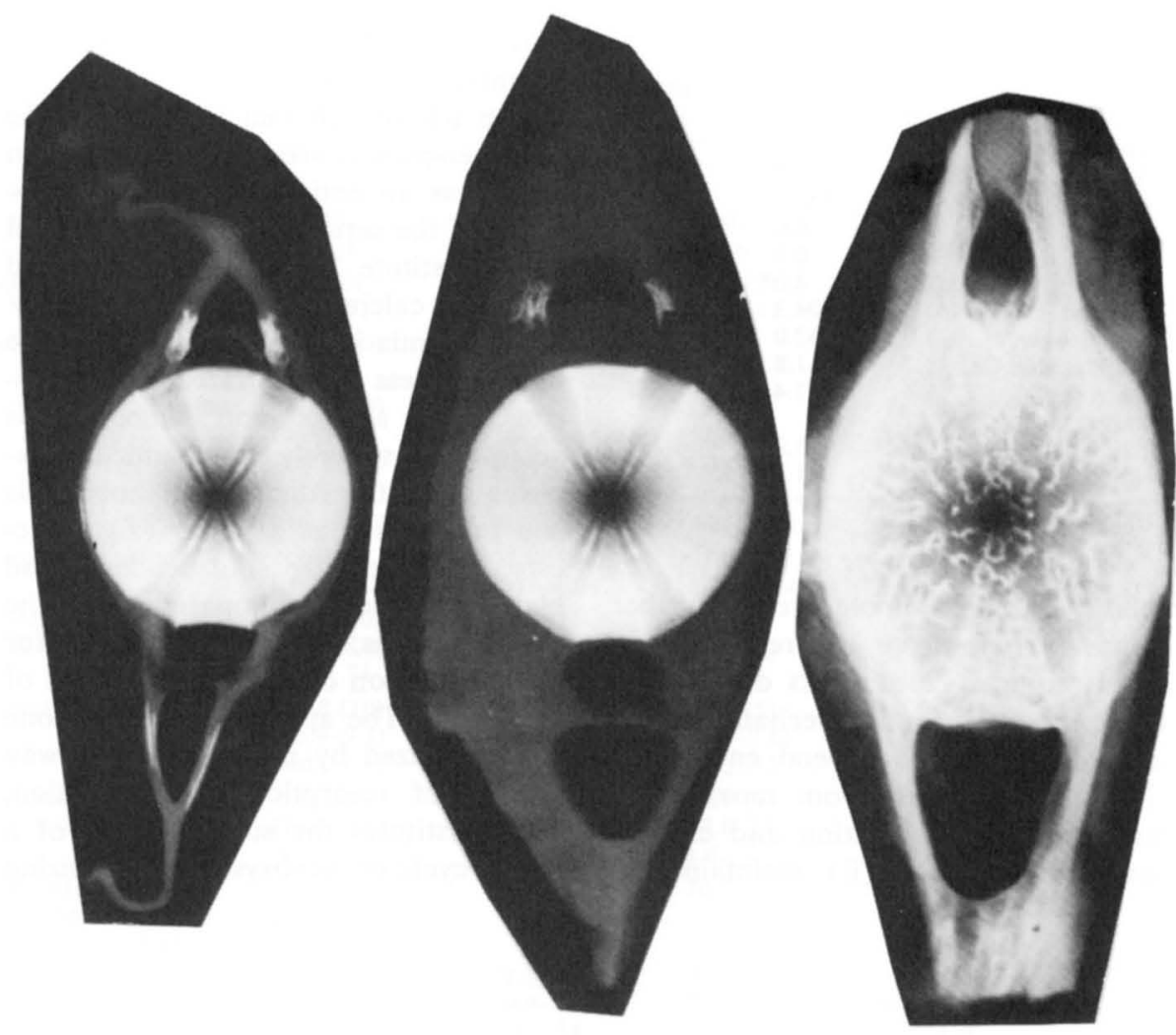

Fig. 1. Radiographs in the frontal view, showing the anatomy of the lumbar vertebrae of $C$. leucas leucas (left), C. leucas nicaraguensis (middle), and the tarpon, $M$. atlanticus (right). These deposits consist of calcified cartilage in the elasmobranchs, but true bone exists in the teleosts. The identical pattern in the two sharks suggests that they are of very closely related, if not the same, species. 
$\mathrm{HCO}_{3}, 3.0$ and 1.7; $\mathrm{SO}_{1}, 0.7$ and 0.7; and $\mathrm{PO}_{4}, 0.001$ and 0.001 .

In C. leucas nicaraguensis from Rio San Juan, the total concentration of the serum is approximately 83 percent, the calcium 66 percent, and the uremia 30 percent of the levels which were found in $C$. leucas from a marine habitat (Table 1). To appreciate the remarkable adjustments that these elasmobranchs can make in fresh water, the chemical composition of the serum in marine habitat (4) must be noted. In the sea, the level of serum urea fiuctuates between 300 and $350 \mathrm{mmole} /$ liter, and the total ion concentration rises and falls only slightly in order to maintain osmotic equilibrium and homeostasis. The ionic strength, $\mu$, is as high as $0.3(7)$. Elasmobranchs do not drink sea water but absorb calcium and other ions from the diet through the gut. The active concentration of calcium ions is sustained by the kidneys and gill membranes at levels required for normal neuromuscular tone and for calcification of cartilage. For these functions, the optimum concentration of total serum calcium $(3.0 \mathrm{mmole} /$ liter is ionized) for the shark in marine

Table 1. Chemical composition (millimoles per liter) of serums of sharks and tarpon.

\begin{tabular}{|c|c|c|c|}
\hline Item & $\begin{array}{c}\text { C. leucas } \\
\text { leucas }\end{array}$ & $\begin{array}{l}\text { C. leucas } \\
\text { nicara- } \\
\text { guensis }\end{array}$ & $\begin{array}{c}M . \\
\text { atlanticus }\end{array}$ \\
\hline \multicolumn{4}{|l|}{ Ions: } \\
\hline $\mathrm{Na}$ & 223.4 & 200.12 & 101.0 \\
\hline $\mathbf{K}$ & 9.0 & $8.2^{*}$ & 6.2 \\
\hline $\mathrm{Ca}$ & 4.5 & 3.0 & 2.5 \\
\hline $\mathbf{M g}$ & 2.9 & 2.0 & 1.4 \\
\hline $\mathrm{Cl}$ & 236.0 & 180.5 & 140.0 \\
\hline $\mathrm{HCO}_{3}$ & 5.1 & 6.0 & 10.1 \\
\hline $\mathrm{SO}_{4}$ & 0.6 & 0.5 & 0.4 \\
\hline $\mathrm{PO}_{4}$ & 2.0 & $4.0^{*}$ & $5.0 *$ \\
\hline Total & 483.5 & 404.3 & 266.6 \\
\hline Urea nitrogen & 333.0 & I 32.0 & 6.0 \\
\hline Ultrafilterable Ca & a $\quad 3.7$ & 1.8 & 1.1 \\
\hline Protein $(\mathrm{g} \%)$ & 2.4 & 3.4 & 6.0 \\
\hline \multicolumn{4}{|l|}{ Alkaline } \\
\hline phosphatase & 0.9 & 3.0 & 2.0 \\
\hline Acid phosphatase & se 1.0 & 1.1 & 12.0 \\
\hline
\end{tabular}

habitat is $4.5 \mathrm{mmole} /$ liter. Further efforts to investigate ion regulation in fishes requires experiments designed to study thermodynamic mechanisms. In sea water, the gills expend energy to: (i) hold back ions from moving too fast toward concentration and electropotential gradients; (ii) maintain uni- directional flow; and (iii) regulate each ion separately. The concentration of calcium in sea water is $10.10 \mathrm{mmole} /$ liter, but only a fraction is chemically active when this value is corrected to infinite dilution and ion association is taken into consideration.

In the fresh water, the serum concentration of urea is sustained at approximately $132 \mathrm{mmole} /$ liter. Elasmobranchs require at least this concentration of urea for normal cardiac function $(7,8)$. The concentration of total ions is $404.3 \mathrm{mmole} /$ liter, 83 percent of the ion concentration of the serum of marine elasmobranchs; the ionic strength, $\mu$, is estimated to be .2790 . Under these conditions, the active concentrations of calcium ions increase to the extent that precipitation of calcium phosphate and depression of neuromuscular irritability can be avoided only if the gill membranes and the kidneys lower the calcium concentration in the body fluids. This level appears in the fresh-water shark to be approximately $3.0 \mathrm{mmole} /$ liter of total and $1.8 \mathrm{mmole} / \mathrm{liter}$ of ultrafilterable calcium. The most abundant ions in Rio San Juan and other bodies of fresh water are $\mathrm{Ca}^{++}$and $\mathrm{HCO}^{--}$, but the total ion concentration is very low (5.1 mmole/liter), compared with $404.3 \mathrm{mmole} / \mathrm{liter}$ in serum. Here, the gills expend energy obtained from intracellular glycolysis to pump ions against concentration and electropotential gradients.

The teleost fish that is found in the same geographic area as the Nicaraguan shark has an entirely different composition of the serum; $\mu$ equals 0.15 , total ions constitute $266.6 \mathrm{mmole} / \mathrm{liter}$, and the total calcium is only $2.5 \mathrm{mmole} /$ liter. Uremia is absent (Table 1). The blood is less concentrated, more viscous, better aerated, and homeostasis is achieved presumably by dynamic mechanisms using the functions of bone cells and bone tissue as a buffer (7). Teleosts are ionically independent and highly advanced, compared with the elasmobranchs; they evolved bone for finer regulation of ionic composition of the blood. The apatite mineral in bone is metabolized by means of a two-way process of resorption and formation, and constitutes the storage depot of a closed cycle or servosystem for utilizing hydronium, sodium, calcium, phosphate, and other ions. In addition to gills, kidneys, and bone, integument functions as an organ of ionic homeostasis. It serves as a semipermeable membrane in lamprey (which have gills but no calcium deposits) and in certain adult amphibians (which possess true bone but no gills and yet retain urea). In elasmobranchs and teleosts, the body covering is waterproof, and facilitates osmoregulation. Thus, the interactions and combinations of organs used by vertebrates for water balance and mineral homeostasis are numerous and highly complex. Physiologic experiments are necessary to measure the capacity of the bull sharks for adaptation. A tagging project would be of great interest to determine the limits of their range, reproductive cycle, species specificity, and ascertain whether they readapt to marine habitat.

Marshall R. URIST

Division of Orthopedics, Department of Surgery, University of California Medical Center, Los Angeles 24

\section{References and Notes}

1. A. W. C. T. Herre, Science 122, 417 (1955). 2. M. Boeseman, ibid. 123, 222 (1956).

3. H. Smith, Am. J. Physiol. 98, 279 (1931).

4. M. R. Urist, Endocrinology 69, 778 (1961).

5. I am indebted to: Dr. Thomas R. Howell, Marc Buchanan, and John Zoeger of the de partment of zoology at UCLA, who assisted and made the arrangements in Nicaragua; $\mathrm{Dr}$. J. Antonio Mora, Ing., Escuela Nacional de Agricultura y Ganaderia, who selected the area of exploration; the Nicaraguan Air Force of exploration; the Nicaraguan Air Force, Major Alvaro Pallais S., Commandant at San Major Alvaro Pallais S., Commandant at San Carlos, who allocated a jeep and boats; Cap tain Humberto Suarez A., of the Guardia $\mathrm{Na}$ cional de Nicaragua, who gave invaluable time and energy and assisted in the surgery; Marshall McLean Urist of Cate School who served as laboratory technician and processsed the specimens; Dr. Eugenie Clark, Cape Haze Marine Laboratory, Placida, Florida, who pro vided serum and vertebrae of $C$. leucas, collected in the Atlantic Ocean; Robert Dorion, Guatemala City, Guatemala, who generously loaned his private library on the Elasmobranchii; Drs. Stewart Springer (Duke University Marine Laboratory), T. B. Thorson (University of Nebraska), and Malcolm Gordon, who contributed valuable suggestions.

6. A. B. Bigelow, W. C. Schroder, S. Springer Bull. Mus. Comp. Zool. 109, 213 (1953).

7. M. R. Urist, Perspectives Biol. Med. (in press)

8. W. W. Simpson and E. Ogden, J. Exptl. Biol. 9, 1 (1932).

9. These investigations were supported by contract NR 104-575 between the Office of Naval Redical Center, Los Angeles, and in part by Medical Center, Los Angeles, and in part by Research.

10 August 1962 